\title{
The effect of different soil properties on arbuscular mycorrhizal colonization of peanuts, sorghum and maize
}

\author{
Rosilaine Carrenho ${ }^{1,4}$, Sandra Farto Botelho Trufem², Vera Lúcia Ramos Bononi² and Eraldo Schunk Silva ${ }^{3}$
}

Received: March 4, 2005. Accepted: January 26, 2007

\begin{abstract}
RESUMO - (Diferentes propriedades do solo na colonização micorrízica arbuscular de amendoim, sorgo e milho). Fungos micorrízicos arbusculares (FMA) são importantes para o crescimento das plantas, pois aumentam o influxo de minerais. Porém, a eficiência simbiótica é afetada por muitos fatores ambientais. Este estudo avaliou os efeitos de diferentes tratamentos (+/- fósforo; +/- calcário; +/- matéria orgânica; texturas de solo arenosa, argilosa e de campo) sobre a colonização radical (CR) de amendoim, sorgo e milho. Da combinação destes fatores resultaram 72 tratamentos. O experimento fatorial foi do tipo $2 \times 2 \times 2 \times 3 \times 3$, com amostragem inteiramente ao acaso. Os dados foram submetidos à análise de variância e ao teste de Tukey $(\mathrm{P} \leq 0,05)$. Três meses após a germinação das sementes, as raízes foram coletadas para avaliação das percentagens de CR. Os resultados mostraram que a textura do solo e a calagem foram os fatores que mais influenciaram a CR em milho, sorgo e amendoim. Diferenças significativas também foram observadas entre os fitobiontes. Matéria orgânica teve influência pouco significativa sobre a CR enquanto adição de fósforo não ocasionou variação.
\end{abstract}

Palavras-chave: micorriza, calagem, textura do solo, matéria orgânica, fósforo

\begin{abstract}
The effect of different soil properties on arbuscular mycorrhizal colonization of peanuts, sorghum and maize). Arbuscular mycorrhizal fungi (AMF) are important for plant growth since they increase mineral influx. However, symbiosis efficiency is affected by many environmental factors. This study evaluated the effects of different treatments (+/- phosphorus; +/- liming; +/organic matter; field, sandy or clayey soil textures) on root colonization (RC) of peanuts, sorghum and maize. The combination of these resulted in seventy-two treatments. The $2 \times 2 \times 2 \times 3 \times 3$ factorial experiment was laid out in a randomized design. All data were subjected to variance analysis and the means were compared (Tukey at $\mathrm{P} \leq 0.05$ ). Three months after seed germination, roots were collected to evaluate the percentage of RC. Results showed that soil texture and liming were the most important factors influencing colonization percentage in maize, sorghum and peanuts by AMF. Significant differences were also observed between the phytobionts. Organic matter (OM) had very little influence and phosphorus addition had no effect on RC.
\end{abstract}

Key words: mycorrhiza, liming, soil texture, organic matter, phosphorus

\section{Introduction}

Arbuscular mycorrhizal fungi (AMF) are important organisms for plants since they can improve mineral uptake and thus may lead to plants that are bigger and more resistant to environmental stresses (Barea et al. 1993). Usually, plant, soil and climatic factors are related to the development of these fungi, and show varied effects on establishment of the mycorrhizal symbiosis and its efficiency. Soil amendments (fertilizers, organic residues, and $\mathrm{pH}$ adjustments), in order to improve crop yields, change the soil properties, and the variations both in plant and fungal responses modify the outcome of the symbiosis. Reviews made by
Thompson (1994), Smith \& Read (1997a) and Entry et al. (2002) are excellent sources of additional information on these issues.

Understanding the influence of these factors on the mycorrhizal partners is important because the balance of this symbiosis may underpin projects involving the conservation of natural areas and the recovery of disturbed ones, as well as management practices in agricultural and forest areas.

Production of mycorrhizal propagules (spores, hyphae and colonized roots) permits the inoculation of these organisms in plants growing in soils where AMF inoculum levels are reduced, and this is an important part of the process of soil microbiota recuperation (Smith \& Read 1997b).

\footnotetext{
1 Universidade Estadual de Maringá, Departamento de Biologia, Av. Colombo 5790, 87020-900 Maringá, PR, Brasil

2 Instituto de Botânica, C. Postal 3005, 01061-970 São Paulo, SP, Brazil

3 Universidade Estadual de Maringá, Departamento de Estatística, Av. Colombo 5790, 87020-900 Maringá, PR, Brasil

4 Author for correspondence: rcarrenho@uem.br
} 
This study was carried out to investigate the effects of different growth conditions (variations in texture, $\mathrm{pH}$, phosphorus concentration and organic matter content of the soil) on mycorrhizal colonization of three crops (peanut, sorghum and maize). In order to define the best conditions for the production of this kind of propagule, each factor was first evaluated individually and later, combined at different levels, since in the soil these normally operate together and their effects on plants is the result of a sum of responses.

\section{Material and methods}

Study area - The experimental area is located in the Moji-Guaçu Biological Reserve and Experimental Station (Fazenda Campininha), Martinho Prado district, São Paulo state, at $22^{\circ} 18^{\prime} \mathrm{S}$ and $47^{\circ} 11^{\prime} \mathrm{W}$, and at an elevation of $680 \mathrm{~m}$ (Barbosa et al. 1993). The climate is characterized as Cwa, (Köppen classification), with dry winters and average temperatures close to $16{ }^{\circ} \mathrm{C}$ in the coldest month and to $24{ }^{\circ} \mathrm{C}$ in the hottest. The soil is a dystrophic sandy Yellow Red Latosol (Batista 1988).

Experimental design - This $2 \times 2 \times 2 \times 3 \times 3$ factorial experiment was laid out in a randomized design, with variation in the following soil factors: $\mathrm{pH}$ (with or without calcium carbonate), organic matter (with or without $\mathrm{OM}$ ), phosphorus (with or without $\mathrm{P}$ ) and texture (field/sandy/clayey) and the following host plants: peanut, sorghum and maize. The combination of these components produced 72 treatments. Six replicates were made of each treatment, and 432 individuals were evaluated.

Phytobionts - The plants studied were maize (Zea mays L. variety IAC Taiúba), peanut (Arachis hypogaea L. variety Tatú) and sorghum (Sorghum bicolor (L.) Moench variety AG 1017). These species were chosen because all have been used in the multiplication of AMF spores (Sieverding 1991; Morton et al. 1993). Thus, we can compare our results with those from studies carried out previously.

Installation - The substrata were put into plastic bags (capacity of $1.5 \mathrm{~kg}$ of soil) appropriate for seedling production. The bags were placed on tables, which were arranged in the field under water sprinkler heads. Each bag was inoculated with approximately 250 spores multiplied previously on maize, peanut or sorghum (Carrenho et al. 2002). The inoculum constituted of a mixture of 14 species coming from the three plants, with a predominance of Glomus (seven taxa, with approximately $80 \%$ of the total number of spores). The inoculum was inserted into the central area of the bags, $5 \mathrm{~cm}$ deep. Immediately above this, three seeds were deposited per bag. After the emergence of the seedlings, the weaker ones were taken out, leaving only the most vigorous plant.

Agricultural practices - Three months before the beginning of the experiment (September/1996), field soil was amended with $25 \mathrm{~kg}$ of calcareous dolomite, corresponding to $1.136 \mathrm{mg} \mathrm{L}^{-1}$. Chemical and physicalchemical analyses of the soils of all substrata were done (Tab. 1) one month after the start of the experiment (January/1997). The substrata that received phosphorus were supplemented with $166.6 \mathrm{mg}$ of a simple superphosphate mixture per liter of soil, around $30 \mathrm{mg}$ of available phosphorus. In the substrata with clayey soil, sandy soil and organic matter, clay, river sand (previously disinfected with methyl bromide) and triturated Sphagnum, respectively, were added to the field soil in a proportion of 2:8 (v:v).

Each bag received $10 \mathrm{mg}$ of nitrogen and $20 \mathrm{mg}$ of potassium per liter of soil, through ammonia sulfate and potassium chloride, respectively. Thirty days after seedling emergence, new applications of nitrogen $(10 \mathrm{mg})$ were made.

Collections - Three months after the seeds had germinated, the plants were subjected to drought stress for one week. The shoots were cut back soon after and the roots were separated. The thinnest roots present in each bag were removed and put into glass flasks with FAA (formalin, alcohol, acetic acid 1:1:1) until clearing and staining.

Evaluation of the root colonization - Approximately two grams of roots (per bag) were separated from the substratum by wet sieving, washed in tap water and stained with trypan blue (Phillips \& Hayman 1970). The presence or absence of AMF structures inside the roots, as well as the extension of colonization, were measured using the intersection of quadrants method (Giovannetti \& Mosse 1980).

Statistical analysis - In this experiment, a standard procedure of variance analysis was used (Complete Factorial Model - ANOVA), and treatment means were compared using Tukey's Studentized Range Test $(\mathrm{p}=0.05)$. Percentage data were arcsine-transformed prior to the analysis. In order to discuss the results, only significant interactions with up to three factors were considered. 
Table 1. Chemical characteristics of the soil treatments tested.

\begin{tabular}{|c|c|c|c|c|c|c|c|c|c|c|}
\hline Treatments ${ }^{1}$ & $\begin{array}{c}\mathrm{pH} \\
\left(\mathrm{CaCl}_{2}\right)\end{array}$ & $\begin{array}{c}\mathrm{OM} \\
\left(\mathrm{g} \cdot \mathrm{dm}^{-3}\right)\end{array}$ & $\mathrm{K}$ & $\mathrm{Ca}$ & $\begin{array}{c}\mathrm{Mg} \\
\left(\mathrm{mmol}_{\mathrm{c}} \cdot \mathrm{dm}^{-3}\right)\end{array}$ & $\mathrm{H}+\mathrm{Al}$ & $\mathrm{SB}$ & CEC & $\begin{array}{c}\mathrm{V} \\
(\%)\end{array}$ & $\begin{array}{c}\mathrm{P} \\
\left(\mathrm{mg} \cdot \mathrm{dm}^{-3}\right)\end{array}$ \\
\hline & \multicolumn{10}{|c|}{ Field soil } \\
\hline $\mathrm{L}-\mathrm{OM}-\mathrm{P}-$ & 6.0 & 18.0 & 0.09 & 2.8 & 1.5 & 1.8 & 4.4 & 6.2 & 71.0 & 12.0 \\
\hline $\mathrm{L}-\mathrm{OM}+\mathrm{P}-$ & 5.2 & 22.0 & 0.13 & 1.6 & 0.9 & 2.5 & 2.6 & 5.1 & 51.0 & 7.0 \\
\hline $\mathrm{L}-\mathrm{OM}-\mathrm{P}+$ & 6.0 & 16.0 & 0.10 & 2.7 & 1.4 & 1.6 & 4.2 & 5.8 & 72.0 & 14.0 \\
\hline $\mathrm{L}-\mathrm{OM}+\mathrm{P}+$ & 6.0 & 19.0 & 0.11 & 2.7 & 1.5 & 1.6 & 4.3 & 5.9 & 73.0 & 12.0 \\
\hline $\mathrm{L}+\mathrm{OM}-\mathrm{P}-$ & 6.9 & 13.0 & 0.06 & 4.5 & 2.1 & 1.1 & 6.7 & 7.8 & 86.0 & 27.0 \\
\hline $\mathrm{L}+\mathrm{OM}+\mathrm{P}-$ & 6.9 & 16.0 & 0.12 & 4.2 & 2.1 & 1.1 & 6.4 & 7.5 & 85.0 & 24.0 \\
\hline $\mathrm{L}+\mathrm{OM}-\mathrm{P}+$ & 7.0 & 11.0 & 0.14 & 5.2 & 2.9 & 1.0 & 8.2 & 9.2 & 89.0 & 34.0 \\
\hline \multirow[t]{2}{*}{$\mathrm{L}+\mathrm{OM}+\mathrm{P}+$} & 7.0 & 15.0 & 0.12 & 4.5 & 2.0 & 1.1 & 6.6 & 7.7 & 86.0 & 27.0 \\
\hline & \multicolumn{10}{|c|}{ Sandy soil } \\
\hline $\mathrm{L}-\mathrm{OM}-\mathrm{P}-$ & 5.2 & 15.0 & 0.08 & 1.3 & 0.8 & 2.3 & 2.2 & 4.5 & 49.0 & 8.0 \\
\hline $\mathrm{L}-\mathrm{OM}+\mathrm{P}-$ & 5.1 & 22.0 & 0.13 & 1.6 & 0.9 & 2.5 & 2.6 & 5.1 & 51.0 & 7.0 \\
\hline $\mathrm{L}-\mathrm{OM}-\mathrm{P}+$ & 5.2 & 18.0 & 0.11 & 1.3 & 0.8 & 2.3 & 2.2 & 4.5 & 49.0 & 11.0 \\
\hline $\mathrm{L}-\mathrm{OM}+\mathrm{P}+$ & 5.2 & 23.0 & 0.12 & 1.7 & 1.0 & 2.3 & 2.8 & 5.1 & 55.0 & 14.0 \\
\hline $\mathrm{L}+\mathrm{OM}-\mathrm{P}-$ & 7.0 & 15.0 & 0.08 & 5.2 & 2.0 & 1.0 & 7.3 & 8.3 & 88.0 & 20.0 \\
\hline $\mathrm{L}+\mathrm{OM}+\mathrm{P}-$ & 7.0 & 19.0 & 0.16 & 4.8 & 1.9 & 1.1 & 6.9 & 8.0 & 86.0 & 18.0 \\
\hline $\mathrm{L}+\mathrm{OM}-\mathrm{P}+$ & 7.0 & 11.0 & 0.06 & 4.9 & 2.7 & 1.0 & 7.7 & 8.7 & 88.0 & 28.0 \\
\hline \multirow[t]{2}{*}{$\mathrm{L}+\mathrm{OM}+\mathrm{P}+$} & 6.8 & 20.0 & 0.13 & 4.8 & 1.8 & 1.0 & 6.7 & 7.7 & 87.0 & 20.0 \\
\hline & \multicolumn{10}{|c|}{ Clayey soil } \\
\hline $\mathrm{L}-\mathrm{OM}-\mathrm{P}-$ & 6.0 & 18.0 & 0.06 & 2.8 & 1.8 & 1.8 & 4.7 & 6.5 & 72.0 & 9.0 \\
\hline $\mathrm{L}-\mathrm{OM}+\mathrm{P}-$ & 4.5 & 19.0 & 0.10 & 1.1 & 0.7 & 3.1 & 1.9 & 5.0 & 38.0 & 5.0 \\
\hline $\mathrm{L}-\mathrm{OM}-\mathrm{P}+$ & 5.7 & 19.0 & 0.09 & 2.5 & 1.4 & 2.0 & 4.0 & 6.0 & 67.0 & 12.0 \\
\hline $\mathrm{L}-\mathrm{OM}+\mathrm{P}+$ & 5.0 & 22.0 & 0.13 & 1.7 & 1.2 & 2.8 & 3.0 & 5.8 & 52.0 & 8.0 \\
\hline $\mathrm{L}+\mathrm{OM}-\mathrm{P}-$ & 7.0 & 14.0 & 0.09 & 5.9 & 2.7 & 1.1 & 8.7 & 9.8 & 89.0 & 19.0 \\
\hline $\mathrm{L}+\mathrm{OM}+\mathrm{P}-$ & 5.8 & 19.0 & 0.12 & 5.5 & 2.0 & 1.2 & 7.6 & 8.8 & 86.0 & 18.0 \\
\hline $\mathrm{L}+\mathrm{OM}-\mathrm{P}+$ & 7.0 & 13.0 & 0.06 & 5.5 & 2.6 & 1.1 & 8.2 & 9.3 & 88.0 & 28.0 \\
\hline $\mathrm{L}+\mathrm{OM}+\mathrm{P}+$ & 6.8 & 15.0 & 0.11 & 5.1 & 2.6 & 1.2 & 7.8 & 9.0 & 87.0 & 29.0 \\
\hline
\end{tabular}

${ }^{1}$ treatments according to the addition $(+)$ or not $(-)$ of lime $(\mathrm{L})$, organic matter $(\mathrm{OM})$ or phosphorus $(\mathrm{P})$ in soil; $\mathrm{H}+\mathrm{Al}=$ potential acidity; $\mathrm{SB}=$ sum of bases; $\mathrm{CEC}=$ cation exchange capacity; $\mathrm{V}=$ base saturation.

\section{Results and discussion}

The minimal and maximal percentage values of root colonization (RC) were 3.5 and $96.3 \%$, respectively and, in general, the median percentages varied from 40 to $70 \%$. Root colonization was mainly influenced by host plant and soil texture, the first factor being responsible for the highest differences between the averages (Tab. 2).

Maize had the highest RC percentages (50.8\%), independent of soil texture, liming or addition of phosphorus. Peanut and sorghum had lower percentages (46.9 and $34.5 \%$, respectively), and the differences observed between the three plants were statistically significant (Tab. 3).

The highest RC percentages observed in maize could be due to higher compatibility between the AMF present in the inoculum and the plant, since maize was previously used as a trap for the isolation of these microorganisms from the field (Carrenho et al. 2002).
In studies carried out in pots, Adelman \& Morton (1986) similarly demonstrated that percentage of $\mathrm{RC}$, as well as number of spores and extension of external hyphae were higher when phytobiont, AMF inoculum and soil were from the same location.

The root system of peanut is formed by thick roots with few branches and, according to Baylis (1974), this kind of root causes a greater dependence by the plants on mycorrhizal association. Also, leguminous plants favor the mycorrhizal association because this usually assists the symbiosis with Rhizobium, as demonstrated in several studies (Harris et al. 1985; Bethlenfalvay \& Newton 1991).

Characteristics of root surface besides the anatomical structure of the roots may also influence the early stages of the plant-fungus interaction (Brundrett \& Kendrick 1990). Although maize and sorghum have similar roots, the percentages of root colonization detected in each one were completely different. Both species possess a root surface covered 
Table 2. Significance of the factors studied and factorial designs derived, by ANOVA.

\begin{tabular}{|c|c|c|}
\hline Factors & F & $\mathrm{P}>\mathrm{F}$ \\
\hline Plant** & 208.85 & 0.00 \\
\hline Soil $* *$ & 7.90 & 0.00 \\
\hline Plant $\times$ Soil $* *$ & 8.45 & 0.00 \\
\hline Plant $\times$ Liming $* *$ & 15.83 & 0.00 \\
\hline Plant $\times$ Phosphorus $* *$ & 7.34 & 0.00 \\
\hline Soil $\times$ Liming $* *$ & 11.26 & 0.00 \\
\hline Liming $\times$ Phosphorus $*$ & 5.12 & 0.02 \\
\hline Plant $\times$ Soil $\times$ Liming $* *$ & 7.34 & 0.00 \\
\hline $\begin{array}{l}\text { Plant } \times \text { Soil } \times \text { Phosp } \\
\text { horus* }\end{array}$ & 2.9 & 0.02 \\
\hline $\begin{array}{l}\text { Plant } \times \text { Soil } \times \text { Organic } \\
\text { matter* }\end{array}$ & 3.07 & 0.02 \\
\hline Plant $\times$ Liming $\times$ Phosphorus $*$ & 3.86 & 0.02 \\
\hline $\begin{array}{l}\text { Plant } \times \text { Phosphorus } \times \text { Organic } \\
\text { matter** }\end{array}$ & 11.82 & 0.00 \\
\hline Soil $\times$ Liming $\times$ Phosphorus $*$ & 3.39 & 0.03 \\
\hline Soil $\times$ Liming $\times$ Organic matter* & 4.02 & 0.02 \\
\hline $\begin{array}{l}\text { Liming } \times \text { Phosphorus } \times \text { Organic } \\
\text { matter** }\end{array}$ & 7.94 & 0.01 \\
\hline $\begin{array}{l}\text { Plant } \times \text { Liming } \times \text { Phosphorus } \times \\
\text { Organic matter** }\end{array}$ & 8.88 & 0.00 \\
\hline $\begin{array}{l}\text { Soil } \times \text { Liming } \times \text { Phosphorus } \times \\
\text { Organic matter** }\end{array}$ & 5.33 & 0.05 \\
\hline $\begin{array}{l}\text { Plant } \times \text { Soil } \times \text { Liming } \times \text { Phosphorus } \times \\
\text { Organic matter* }\end{array}$ & 2.49 & 0.04 \\
\hline
\end{tabular}

$* \mathrm{P} \leq 0.05 ; * * \mathrm{P} \leq 0.01$.

by two kinds of mucilage: a gelatinous material produced by the root cap, and another firmer and uniformly thickened, attached to the epidermal cells (Mc Cully 1987). In sorghum, when the roots elongate, this mucilaginous mantle is detached with the cortical cells. Thus, the endoderm remains as a root surface; in maize, this mantle is detached only with epidermal and hypodermic cells (Mc Cully 1987). These anatomical differences may influence AMF development and be responsible for the differences observed in $\mathrm{RC}$ percentages, since in the first situation the roots lose the sites where symbiosis is established (cortex).
When the host plant factor was evaluated combined with others (texture, liming, phosphorus and organic matter), it was observed that root colonization in sorghum was significantly reduced in clayey soil, as well as in soil to which lime was added (Tab. 4).

In general, clayey soils are more fertile than sandy ones because clay has a higher capacity for adsorbing ions from the soil solution (Malavolta 1980). In this study high cationic exchange capacity was observed in the clayey soil (5 to 9.8), as shown in Table 1, and this greater nutrient concentration could have limited AMF development, as shown in several studies (Weissenhorn \& Leyval 1996; Eason et al. 1999).

Additionally, the mechanical impediment, caused by a finer soil texture, favors the deposition of suberin on the epidermis (Wilson \& Robards 1978), which increases resistance to infection by AMF (Esau 1965 apud Koske \& Gemma 1995). With reduced space between the soil particles, mechanical stress on the roots is increased, so that breakage of the cortical layers is increased and the colonization sites are lost.

Amending soil acidity with lime also favors nutrient availability (Malavolta 1980). This could have reduced the dependence of the host plants on the mycorrhizal association.

Mycorrhizal colonization in peanut plants was significantly depressed by adding phosphorus (Tab. 4). Addition of phosphorus generally diminished RC by AMF (Abbott \& Robson 1991). As the depressive effect of phosphorus on RC was observed only in peanut plants, it is probable that the nutrient uptake capacity of this plant is different from the other two. The root system of leguminous plants is less developed than that of grasses and it is reasonable to suppose that their ability for nutrient absorption is greater, to attend to the demand needed for plant growth (Bennie 1996). Thus, the supplementation of phosphorus in the substratum may have increased the concentration of this element in the plant tissues, and this could have diminished the liberation of root exudates, by reducing

Table 3. Percentage of root colonization by AMF in different plants, and under varied soil conditions.

\begin{tabular}{|c|c|c|c|c|c|c|c|c|c|}
\hline \multicolumn{2}{|l|}{ Plant } & \multicolumn{2}{|c|}{ Soil texture } & \multicolumn{2}{|c|}{ Liming } & \multicolumn{2}{|c|}{ Phosphorus } & \multicolumn{2}{|c|}{ Organic matter } \\
\hline Peanut & $46.9 \mathrm{~b}$ & Field & $44.5 \mathrm{ab}$ & No & 44.7 & No & 44.5 & No & 44.5 \\
\hline Sorghum & $34.5 \mathrm{c}$ & Sandy & $45.6 \mathrm{a}$ & Yes & 43.5 & Yes & 43.7 & Yes & 43.7 \\
\hline Maize & $50.8 \mathrm{a}$ & Clayey & $42.3 \mathrm{~b}$ & & & & & & \\
\hline \multicolumn{2}{|c|}{$\mathrm{P} \leq 0.01 ;$ 1.s.d. 2.37} & \multicolumn{2}{|c|}{$\mathrm{P} \leq 0.01 ;$ 1.s.d. 2.37} & n.s & n.s & n.s & & & \\
\hline
\end{tabular}

n.s = not significant; 1.s.d. = least significant difference. Averages followed by the same letters do not differ from each other, at the $5 \%$ level, according to Tukey's Studentized Range Test. 
Table 4. Individual or combined influence of some soil properties on the percentage of root colonization by AMF in different plants.

\begin{tabular}{|c|c|c|c|}
\hline Soil treatments and interactions & Peanut & Sorghum & Maize \\
\hline \multicolumn{4}{|l|}{ Plant $\times$ Soil texture $(\mathrm{P} \leq 0.01 ;$ 1.s.d. 4.11$)$} \\
\hline Field texture & $47.4 \mathrm{Aa}$ & $37.9 \mathrm{Ab}$ & $48.1 \mathrm{Ba}$ \\
\hline Sandy texture & $47.4 \mathrm{Ab}$ & $35.8 \mathrm{Ac}$ & $53.4 \mathrm{Aa}$ \\
\hline Clayey texture & $46.1 \mathrm{Ab}$ & $29.7 \mathrm{Bc}$ & $51.1 \mathrm{ABa}$ \\
\hline \multicolumn{4}{|l|}{ Plant $\times$ Liming $(P \leq 0.01 ;$ 1.s.d. 3.35$)$} \\
\hline Liming & $47.6 \mathrm{Ab}$ & $31.2 \mathrm{Bc}$ & $51.8 \mathrm{Aa}$ \\
\hline No Liming & $46.3 \mathrm{Ab}$ & $37.3 \mathrm{Ac}$ & $49.9 \mathrm{Aa}$ \\
\hline \multicolumn{4}{|l|}{ Plant $\times$ Phosphorus $(\mathrm{P} \leq 0.01$; 1.s.d. 3.35) } \\
\hline Phosphorus & $44.7 \mathrm{Bb}$ & $34.7 \mathrm{Ac}$ & $51.6 \mathrm{Aa}$ \\
\hline No Phosphorus & $49.2 \mathrm{Aa}$ & $34.2 \mathrm{Ab}$ & $50.2 \mathrm{Aa}$ \\
\hline \multicolumn{4}{|c|}{ Plant $\times$ Texture $\times$ Liming $(P \leq 0.01 ;$ 1.s.d. 5.81$)$} \\
\hline Field texture $\times$ Liming & $44.6 \mathrm{Ba}$ & $35.5 \mathrm{Bb}$ & $45.0 \mathrm{Ba}$ \\
\hline Field texture $\times$ no Liming & $50.1 \mathrm{Aa}$ & $40.4 \mathrm{Ab}$ & $51.2 \mathrm{Aa}$ \\
\hline Sandy texture $\times$ Liming & $50.6 \mathrm{Ab}$ & $29.7 \mathrm{Bc}$ & $56.1 \mathrm{Aa}$ \\
\hline Sand texture $\times$ no Liming & $44.3 \mathrm{Bb}$ & $41.8 \mathrm{Ab}$ & $50.8 \mathrm{Ba}$ \\
\hline Clayey texture $\times$ Liming & $47.7 \mathrm{Ab}$ & $28.3 \mathrm{Bc}$ & $54.3 \mathrm{Aa}$ \\
\hline Clayey texture $\times$ no Liming & $44.5 \mathrm{Ba}$ & $31.1 \mathrm{Bb}$ & $47.8 \mathrm{Ba}$ \\
\hline \multicolumn{4}{|l|}{ Plant $\times$ Texture $\times$ Phosphorus $(\mathrm{P} \leq 0.05)$} \\
\hline Field texture $\times$ Phosphorus & 46.4 & 36.9 & 49.3 \\
\hline Field texture $\times$ no Phosphorus & 48.2 & 39.0 & 46.8 \\
\hline Sandy texture $\times$ Phosphorus & 42.7 & 48.7 & 46.1 \\
\hline Sandy texture $\times$ no Phosphorus & 52.2 & 34.1 & 53.7 \\
\hline Clayey texture $\times$ Phosphorus & 44.9 & 29.8 & 52.2 \\
\hline Clayey texture $\times$ no Phosphorus & 47.3 & 29.6 & 49.9 \\
\hline \multicolumn{4}{|c|}{ Plant $\times$ Phosphorus $\times$ organic matter $(\mathrm{P} \leq 0.01 ; 1$. s.d. 4.74$)$} \\
\hline Phosphorus $\times$ Organic matter & $42.9 \mathrm{Bb}$ & $31.9 \mathrm{Bc}$ & $51.5 \mathrm{Aa}$ \\
\hline Phosphorus $\times$ no Organic matter & $46.6 \mathrm{Ab}$ & $37.5 \mathrm{Ac}$ & $51.6 \mathrm{Aa}$ \\
\hline No phosphorus $\times$ Organic matter & $45.8 \mathrm{Ba}$ & $35.3 \mathrm{Ab}$ & $50.4 \mathrm{Aa}$ \\
\hline No phosphorus $\times$ no Organic matter & $51.6 \mathrm{Aa}$ & $33.1 \mathrm{Ab}$ & $49.9 \mathrm{Aa}$ \\
\hline
\end{tabular}

n.s = not significant; 1.s.d. = least significant difference. Averages followed by the same letters do not differ from each other, at the $5 \%$ level, according to Tukey's Studentized Range Test; lower case letters refer to the lines, upper case letters refer to the columns.

cellular permeability (Koske \& Gemma 1995). Low levels of exudates in the rhizosphere lead to reduced attraction of the germinating hyphae to the roots (Tawaraya et al. 1998).

When maize was cultivated in field soil, the RC percentages were lower than in the other two textures (Tab. 4). It is likely that field soil offered better conditions for maize growth because it contained more nutrients than sandy soil (Tab. 1). Also, it does not restrict root expansion, and consequently the exploitation capacity of the roots, usually observed in less porous soils.

Concerning soil texture, it was observed that sandy soil stimulated the development of mycorrhizal association while clayey soil inhibited it (statistically different median RC percentages), but not those observed in the field soil (Tab. 3).

Sandy soils are usually more porous, warmer, drier, and less fertile than those of a finer texture and these conditions have direct and indirect effects on AMF
(Sylvia \& Williams 1992). Good soil aeration is a prerequisite for optimum AMF development (Saif 1981). Soil temperatures from 30 to $35^{\circ} \mathrm{C}$ favor spore germination (Tommerup 1983), spread of root colonization (Bowen 1987) and arbuscule formation (Schenck \& Schroder 1974). Dry soils (0-1.4MPa) tend to favor AMF spore germination, for example for Gigaspora gigantea (Nicol. \& Gerd.) Gerd. \& Trappe (Wilson 1984), Glomus caledonium (Nicol. \& Gerd.) Trappe \& Gerd., Scutellospora calospora (Nicol. \& Gerd.) Walker \& Sanders and Acaulospora laevis Gerd. \& Trappe (Tommerup 1983). Soil fertility is also considered an important factor in the control of mycorrhizal association (Louis \& Lim 1987), and it generally influences the aforementioned factors. Thus, the effects add up, and the difference in RC percentages may be due to some or all of these factors. Soils with low fertility limit plant development and increase the dependence of plants on mycorrhizal association (Siqueira \& Saggin Júnior 1995). Under 
these circumstances, fungi grow more extensively inside the root to support the development and functioning of external hyphae (Sanders et al. 1977).

Considering merely the soil properties, it was verified that colonization by AMF was affected only when texture and liming were combined. Application of lime lowered the RC percentages in field soil, increased them in clayey soil and did not affect cortical colonization in sandy soil (Tab. 5).

The decrease verified in the field soil is probably related to high soil fertility levels (Tab. 1), which reduced the dependence of the plants on mycorrhizae and restricted the development of these fungi to their root cortex (Sanchez \& Salinas 1981).

Although clayey soils are, in general, more fertile than sandy soils, they rarely represent the best growth medium for plants. A high level of clay can increase cationic exchange capacity and, consequently, soil acidity (see values of CEC and $\mathrm{pH}$ in Table 1). High acidity enhances the potential for cationic percolation, which will immobilize phosphate. The lower the soil $\mathrm{pH}$, the higher the amount of phosphate fixed in the soil, and therefore the lower its availability to the plant (Janos 1987).

Acid soils commonly have poorer structure, lower water and root penetration, less heterotrophic microorganisms and more toxic ions than those with basic $\mathrm{pH}$ (Hoyt et al. 1967). These factors associated with the previous ones harm plant growth. Thus, plants become more susceptible and responsive to mycorrhizal colonization. This could explain the higher percentages observed in the no-lime field and sandy soils (Tab. 5).

Liming altered the intra-radical development of AMF in the interaction plant $\times$ soil (Tab. 4). Application of lime decreased $\mathrm{RC}$ in all host species grown in field soil, as well as in sorghum cultivated in sandy soil. Even so, peanut and maize showed higher percentages (50.6\% vs. $44.3 \%$ and $56.1 \%$, vs. $50.8 \%$, respectively) when this last soil type was treated with lime. The depressive effect observed in the first condition could be explained by a lower requirement of the plant for symbiosis, since nutrient availability was increased after the amendment of soil acidity (Sanchez \& Salinas 1981). It is possible that sorghum is less dependent on AMF than peanut and maize, due to its more branched and thinner root system (Robertson et al. 1980).

Lime, phosphorus and organic matter increments when considered separately did not significantly affect mycorrhizal development. However, when these three factors were combined, it was observed that inclusion of organic matter was harmful to AMF development whenever phosphorus and/or lime were included in the treatments (Tab. 5). Many studies have evaluated the influence of organic matter on arbuscular mycorrhizae (St John et al. 1983; Joner \& Jakobsen 1995; Douds et al. 1997; Gaur \& Adholeya 2002; Gryndler et al. 2002) with very different results, indicating variable responses on plants and fungi. Microbial activity was probably intensified after the addition of organic matter, increasing the concentration of nutrients in the soil (Beyer et al. 1999). This may have reduced the internal growth of AMF for the reasons discussed above.

In conclusion, we observed that some of the factors evaluated had a significant influence on root colonization by AMF. Plant species, soil $\mathrm{pH}$, phosphorus and organic matter levels had already been seen as influencing the intra-radical development of these fungi and our study has reinforced the significance of these factors on the association. The effects produced by

Table 5. Combined influence of some soil properties on the percentage of root colonization by AMF.

\begin{tabular}{|c|c|c|c|c|c|c|}
\hline Soil treatments and interactions & $\mathrm{L}$ & no L & $\mathrm{P}$ & no $\mathrm{P}$ & $\mathrm{OM}$ & no $\mathrm{OM}$ \\
\hline Field texture & $41.7 \mathrm{Bb}$ & $47.2 \mathrm{Aa}$ & 44.2 & 44.7 & 44.8 & 44.1 \\
\hline Sandy texture & $45.5 \mathrm{Aa}$ & $45.7 \mathrm{Aa}$ & 44.5 & 46.7 & 44.3 & 46.8 \\
\hline Clayey texture & $43.5 \mathrm{ABa}$ & $41.1 \mathrm{Bb}$ & 42.3 & 42.2 & 42.2 & 42.4 \\
\hline Liming $(\mathrm{L}) \times$ Phosphorus $(\mathrm{P})$ & & & & & $42.6 \mathrm{Ba}$ & $43.3 \mathrm{Aa}$ \\
\hline No liming $($ no $L) \times$ Phosphorus $(\mathrm{P})$ & & & & $42.1 \mathrm{Ba}$ & $44.8 \mathrm{Aa}$ & \\
\hline Liming $(\mathrm{L}) \times$ no Phosphorus (no P) & & & & & $41.9 \mathrm{Bb}$ & $44.5 \mathrm{Aa}$ \\
\hline No liming (no L) $\times$ no Phosphorus (no P) & & & & $46.4 \mathrm{Aa}$ & $45.3 \mathrm{Aa}$ & \\
\hline \multicolumn{7}{|c|}{ InteractionsSoil texture $\times$ Liming $(\mathrm{P} \leq 0.01$; 1.s.d. 3.35) } \\
\hline \multicolumn{7}{|c|}{ Soil texture $\times$ Phosphorus - n.s } \\
\hline \multicolumn{7}{|l|}{ Soil texture $\times$ Organic matter $-\mathrm{n} . \mathrm{s}$} \\
\hline Liming $\times$ Phosphorus $\times$ Organic matter $(\mathrm{P}$ & 3.43) & & & & & \\
\hline
\end{tabular}

n.s = not significant; 1.s.d. = least significant difference. Averages followed by the same letters do not differ from each other, at the 5\% level, according to Tukey's Studentized Range Test; lower case letters refer to the lines, upper case letters refer to the columns. 
soil texture have been less studied, but our results clearly demonstrate its importance as a regulating factor on mycorrhizal colonization. Also, it was verified that the sum of factors (combined actions), in some cases, modified the isolated responses of these on percentages of root colonization.

\section{References}

Abbott, L.K. \& Robson, A.D. 1991. Field management of VA mycorrhizal fungi. Pp.355-362. In: D.L Keister. (ed.). The rhizosphere and plant growth. Kluwer Academic Publishers, Dordrecht.

Adelman, M.J. \& Morton, J.B. 1986. Infectivity of vesiculararbuscular mycorrhizal fungi: influence of host-soil diluent combinations on MPN estimates and percentage colonization. Soil Biology and Biochemistry 18: 77-83.

Barbosa, L.M.; Barbosa, J.M.; Bedinelli, C.; Asperti, L.M.; Belasque, E.F. \& Batista, E.A. 1993. Efeitos de geadas em mudas de espécies arbóreas de mata ciliar utilizadas em ensaios. Acta Botanica Brasilica 7: 95-105.

Barea, J.M.; Azcón, R. \& Azcón-Aguilar, C. 1993. Mycorrhiza and crops. Advances on Plant Pathology 9:167-189.

Batista, E.A. 1988. Influência de fatores edáficos no cerrado da reserva biológica de Mogi-Guaçu, SP. Tese de Doutorado. Universidade de São Paulo, Piracicaba.

Baylis, G.T.S. 1974. The magnoloid mycotrophin root systems derived from it. Pp. 373-389. In: F.E Sanders; B. Mosse \& P.B. Tinker (eds.). Endomycorrhizae. Academic Press, London.

Bennie, J. 1996. Growth and mechanical impedance. Pp.453470. In: Y. Waisel; A. Eshel \& V. Kafkafi (eds.). Plant roots - the hidden half. 2 ed. Marcel Dekker, New York.

Bethlenfalvay, G.J. \& Newton, W.E. 1991. Agro-ecological aspects of the mycorrhizal, nitrogen-fixing legume symbiosis. Beltsville Symposium in Agricultural Research 14: 349-354.

Beyer, L.; Sieling, K. \& Pingpank, K. 1999. The impact of a low humus level in arable soils on microbial properties. Biology and Fertility of Soils 28: 156-161.

Bowen, G.D. 1987. The biology and physiology of infection and its development. Pp.27-70. In: G.R. Safir (ed.). Ecophysiology of mycorrhizal plants. CRC Press, Boca Raton.

Brundrett, M. \& Kendrick, B. 1990. The roots and mycorrhizas of herbaceous woodland plants. II. Structural aspects of morphology. New Phytologist 114:469-479.

Carrenho, R.; Trufem, S.F.B. \& Bononi, V.L.R. 2002. Effects of using different host plants on the detected biodiversity of arbuscular mycorrhizal fungi from an agroecosystem. Revista Brasileira de Botânica 25: 93-101.

Douds, D.D.; Galvez, L.; Franke-Snyder, M.; Reider, C. \& Drinkwater, L.E. 1997. Effect of compost addition and crop rotation point upon VAM fungi. Agriculture, Ecosystems and Environment 65: 257-266.
Eason, W.R.; Scullion, J. \& Scot, E.P. 1999. Soil parameters and plant responses associated with arbuscular mycorrhizas from contrasting grassland management regimes. Agriculture, Ecosystems and Environments 73: 245-255.

Entry, J.A.; Rygiewicz, P.T.; Watrud, L.S. \& Donnelly, P.K. 2002. Influence of adverse soil conditions on the formation and function of arbuscular mycorrhizas. Advances in Environmental Research 7: 123-138.

Gaur, A. \& Adholeya, A. 2002. Arbuscular mycorrhizal inoculation of five tropical fodder crops and inoculum production in marginal soil amended with organic matter. Biology and Fertility of Soils 35: 214-218.

Giovannetti, M. \& Mosse, B. 1980. An evaluation of techniques for measuring vesicular-arbuscular mycorrhizal infection in roots. New Phytologist 84: 489-500.

Gryndler, M.; Vosátka, M.; Hrselová, H.; Chvátalová, I. \& Jansa, J. 2002. Interaction between arbuscular mycorrhizal fungi and cellulose in growth substrate. Applied Soil Ecology 19: 279-288.

Harris, D.; Pacovsky, R.S. \& Paul, E.A. 1985. Carbon economy of soybean - Rhizobium - Glomus association. New Phytologist 101: 427-440.

Hoyt, P.B.; Henning, A.M.F. \& Dobb J.L. 1967. Reaction of barley and luzern at liming on solonetz, podzol and gley soils. Canadian Journal of Soil Science 47: 15-21.

Janos, D.P. 1987. VA mycorrhizas in humid tropical ecosystems. Pp.107-134. In: G.R. Safir (ed.). Ecophysiology of VA mycorrhizal plants. CRC Press, Boca Raton.

Joner, E.J. \& Jakobsen, I. 1995. Growth and extracellular phosphate activity of arbuscular mycorrhizal hyphae as influenced by soil organic matter. Soil Biology and Biochemistry 27: 1153-1159.

Koske, R.E. \& Gemma, J.N. 1995. Fungal reactions to plants prior to mycorrhizal formation. Pp.3-36. In: M.F. Allen (ed.). Mycorhizal functioning: an integrative plant fungal processes. New York, Chapman and Hall.

Louis, I.M. \& Lim, G. 1987. Spore density and root colonization of vesicular-arbuscular mycorrhizas in tropical soil. Transactions of British Mycological Society 88: 207-212.

Malavolta, E. 1980. O solo como fornecedor de nutrientes. Pp. 16-43. In: Elementos de nutrição mineral de plantas. E. Malavolta (ed.). São Paulo, Editora Ceres.

Mc Cully, M.E. 1987. Selected aspects of the structure and development of field-grown roots with special reference to maize. Pp. 53-70. In: F.J. Gregory; J.V. Lake \& D.A. Rose (eds.). Root development and function. Society for Experimental Biology, Seminar Series no. 30. Cambridge University Press, Cambridge.

Morton, J.B.; Bentivenga, S.P. \& Wheeler, W.W. 1993. Germ plasm in the International Collection of Arbuscular and Vesicular-Arbuscular Mycorrhizal Fungi (INVAM) and procedures for culture development, documentation and storage. Mycotaxon 48: 491-528. 
Phillips, J.M. \& Hayman, D.S. 1970. Improved procedures for clearing roots for rapid assessment of infection. Transactions of British Mycological Society 55: 158-161.

Robertson, W.K.; Hammond, L.C.; Johnson, J.T. \& Boote, K.J. 1980. Effects of plant water stress on root distribution of corn, soybeans, and peanuts in a sandy soil. Agronomy Journal 72: 548-550.

Saif, S.R. 1981.The influence of soil aeration on the efficiency of vesicular-arbuscular mycorrhiza. I. Effect of soil oxygen on the growth and mineral uptake of Eupatorium odoratum L. inoculated with Glomus macrocarpus. New Phytologist 88: 649-659.

Sanchez, P.A. \& Salinas, J.G. 1981. Low-input technology for managing oxisols and ultisols in tropical America. Advances in Agronomy 34: 279-406.

Sanders, F.E.; Tinker, P.B.; Black, R.L.B. \& Palmerley, S.M. 1977. The development of endomycorrhizal root systems. I. Spread of infection and growth-promoting effects with four species of vesicular-arbuscular endophyte. New Phytologist 78: 553-559.

Schenck, N.C. \& Schroder, V.N. 1974. Temperature response of Endogone mycorrhiza on soybean roots. Mycologia 66: 600-605.

Sieverding, E. 1991. Establishment and evaluation of VAM fungal germ plasm. Pp.192-196. In: E. Sieverding (ed.). Vesicular-arbuscular mycorrhiza management in tropical agrosystems. Eschborn, Technical Cooperation.

Siqueira, J.O. \& Saggin-Júnior, O.J. 1995. The importance of mycorrhizal association in natural low-fertility soils. Pp.240-280. In: Anais do Simpósio Internacional sobre Estresse Ambiental. Belo Horizonte 1992: EMBRAPA/ CNPMS, Sete Lagoas.

Smith, S.E. \& Read, D.J. 1997a. Vesicular-arbuscular mycorrhizas in agriculture and horticulture. Pp.453-469. In: S.E. Smith \& D.J. Read (eds.). Mycorrhizal symbiosis. London, Academic Press.
Smith, S.E. \& Read, D.J. 1997b. The roles of mycorrhizas in ecosystems. Pp.409-452. In: S.E. Smith \& D.J. Read (eds.). Mycorrhizal symbiosis. London, Academic Press.

St John, T.V.; Coleman, D.C. \& Reid, C.P.P. 1983. Association of vesicular-arbuscular mycorrhizal hyphae with soil organic particles. Ecology 64: 957-959.

Sylvia, D.M. \& Williams, S.E. 1992. Vesicular-arbuscular mycorrhizae and environmental stress. Pp.101-124. In: G.J. Bethlenfalvay \& R.G. Linderman (eds.). Mycorrhizae in sustainable agriculture. Madison, ASA Special Publication.

Tawaraya, K.; Hashimoto, K. \& Wagatsuma, T. 1998. Effect of root exudate fractions from $\mathrm{P}$-deficient and $\mathrm{P}$-sufficient onion plants on root colonization by the arbuscular mycorrhizal fungus Gigaspora margarita. Mycorrhiza 8: 67-70.

Thompson, J.P. 1994. What is the potential for management of mycorrhizas in agriculture? Pp.191-200. In: A.D. Robson, L.K. Abbott \& N. Malajcuzuk (eds.). Management of mycorrhizas in agriculture, horticulture and forestry. Dordrecht, Kluwer Academic Publishers.

Tommerup, I. C. 1983. Spore dormancy in vesiculararbuscular mycorrhizal fungi. Transactions of British Mycological Society 81: 37-45.

Weissenhorn, I. \& Leyval, C. 1996 Spore germination of arbuscular mycorrhizal fungi in soil differing in heavy metal content and other parameters. European Journal of Soil Biology 32: 165-172.

Wilson, A.J. \& Robards, A.W. 1978. Some observations of the effects of mechanical impedance upon the ultrastructure of the roots caps of barley. Protoplasma 101: 61-72.

Wilson, J.M. 1984. Comparative development of infection by three vesicular-arbuscular mycorrhizal fungi. New Phytologist 97: 413-426. 